\title{
Impact of Seed Lot Infection on the Development of Black Dot and Verticillium Wilt of Potato in Washington
}

\author{
Jeremiah K. S. Dung, Jason T. Ingram, Thomas F. Cummings, and Dennis A. Johnson, Washington State University, Pullman
}

\begin{abstract}
Dung, J. K. S., Ingram, J. T., Cummings, T. F., and Johnson, D. A. 2012. Impact of seed lot infection on the development of black dot and Verticillium wilt of potato in Washington. Plant Dis. 96:1179-1184.

The fungi Colletotrichum coccodes and Verticillium dahliae are two pathogens of potato which are prevalent in potato field soils and seed tubers. The objective of this study was to investigate the influence of seed lot infection by $C$. coccodes and $V$. dahliae on disease severity and yield using infested seed lots and fields with and without potato in their recent cropping histories. Greater incidence of $C$. coccodes in seed led to more root colonization in 2008 (both field types) but not in 2007 and did not influence tuber quantity or yield. Incidence of infection in seed lots by $V$. dahliae was not related to canopy necrosis,

infection of progeny tubers, or yield. However, seed lots exhibited more $V$. dahliae aboveground vascular colonization, canopy necrosis, infested plant debris, and infected progeny tubers in 5-year potato rotation fields compared with long potato rotation fields. In general, foliar disease symptoms and yield reductions were not related to levels of either pathogen in seed lots. Symptoms of both diseases were more severe and yields were lower in fields with potato in their recent cropping histories, emphasizing the importance of soilborne inoculum in the development of black dot and Verticillium wilt of potato.
\end{abstract}

Colletotrichum coccodes (Wallr.) S. Hughes causes potato black dot, which is named from the sclerotia that develop and macroscopically appear as small, black dots on host tissues. The pathogen causes cortical sloughing of roots, and up to $30 \%$ yield reductions have been reported $(14,17,37,40)$. Infected tubers may also exhibit silver to brown lesions and sclerotia which reduces tuber quality, particularly in cultivars destined for the fresh market (33). The pathogen is common in soils of potato-growing regions and, by 1926 , had been reported on five continents (9). Both seed tuberand soilborne inoculum of $C$. coccodes can cause disease (1$3,9,21,30,32,37)$ but several studies have demonstrated that soilborne inoculum results in a greater degree of host plant colonization than tuberborne inoculum $(7,8,26)$. In addition, aboveground stem and foliar infections can occur via wind- or water-borne inoculum, especially if wounds are present, which can result in reduced yields and contribute to stem colonization of potato by $C$. coccodes $(27,30,40)$.

Verticillium wilt of potato, caused by the soilborne fungus Verticillium dahliae Kleb., is also of significant importance to potatogrowing regions around the world. Symptoms of Verticillium wilt of potato include unilateral wilting, chlorosis, and necrosis, which progress acropetally (18). Yield reductions of between 12 and 50\% have been reported but the effects of Verticillium wilt on yield are also influenced by cultural and environmental factors $(6,20,31)$. Although the pathogen is found in the vascular system of infected seed tubers, vascular infection of seed tubers by $V$. dahliae and $V$. albo-atrum, another causal agent of Verticillium wilt of potato, is not as important as soilborne inoculum to disease development, yield reduction, increased progeny tuber infection, or the production of inoculum in infected hosts $(11,13,34)$. However, these previous studies were conducted using artificially inoculated tu-

Corresponding author: J. K. S. Dung, E-mail: dungj@wsu.edu

PPNS number 0589, Department of Plant Pathology, College of Agricultural, Human, and Natural Resource Sciences Agricultural Research Center, project number WNPO 0678, Washington State University, Pullman 991646430 .

Accepted for publication 8 March 2012.

http://dx.doi.org/10.1094/PDIS-01-12-0061-RE

(C) 2012 The American Phytopathological Society bers, cultivars which are under limited current production, or in a greenhouse, and the effect of planting seed lots with varying levels of naturally infected seed tubers under field conditions are not entirely clear.

Certified potato seed lots can be infected by $C$. coccodes and $V$. dahliae at frequencies of 34 and 44\% in Israel (39) and 53 and $29 \%$ in Washington State $(19,29)$, respectively. In 1997, seed lots intended for Washington State production contained up to $90 \%$ of C. coccodes-infected seed tubers (19), while the incidence of seed tuber infection by $V$. dahliae in seed lots was found to be typically less than 5\% (29,39). Although the relative impacts of tuber- and soilborne inoculum on black dot severity and yield reductions have previously been investigated, investigators in these studies used infected tubers with external symptoms or artificially inoculated tubers rather than tubers with natural internal infections $(8,30)$. The role of $V$. dahliae-infected tubers on the development of Verticillium wilt, plant colonization, and reductions in yield has also been previously investigated, but the impact of planting seed lots coinfected by both $V$. dahliae and $C$. coccodes on disease severity and yield is not clear. The objective of this study was to quantify the effect of incidence of seed lot infection by $C$. coccodes and $V$. dahliae on disease development and yield of potato. The hypothesis to be tested was that incidence of infection in seed lots was positively related to disease severity and negatively related to yield. Seed lots with varying incidences of both pathogens were planted in fields planted to regular potato rotations (potato every 5 years) and in fields which had not grown potato for 30 or more years. Information from quantifying the effects of seedborne inoculum on the potato crop should increase the ability to manage both diseases by focusing on the most important sources of primary inoculum.

\section{Materials and Methods}

Planting material and field plots. Ten certified seed lots of 'Russet Burbank' potato were obtained from grower and distributor storages in spring 2007 and 2008. All seed lots were produced in Idaho or Montana and intended for Washington State production fields. The seed lots were classified as generation 3 in accordance with the Washington limited-generation scale (4). Seed tubers (45 $\mathrm{kg}$; approximately 225 tubers) were collected from each seed lot. Seed lots were assayed to determine the incidence of internal infection in seed tubers by $C$. coccodes and $V$. dahliae. Thirty-five randomly selected seed tubers from each seed lot were removed from $4^{\circ} \mathrm{C}$ storage and warmed to $23^{\circ} \mathrm{C}$ for $12 \mathrm{~h}$. The seed tubers were 
washed with soap and water and gently scrubbed with a sponge, rinsed with distilled water, and air dried. A 15-mm-diameter disk, centered on the site of stolon attachment and consisting of periderm, cortex, and vascular tissue, was cut from the basal end of each seed tuber and plated onto NP-10 medium (5) using a flamesterilized scalpel and tweezers. Plates were incubated at $23^{\circ} \mathrm{C}$ in the dark for 14 days and evaluated for colonies of $C$. coccodes and $V$. dahliae. Identification of $C$. coccodes and $V$. dahliae colonies was verified microscopically $(10,16)$. The number of infected tubers was counted and the incidence of $C$. coccodes and $V$. dahliae infection in each seed lot was determined. Of the 10 seed lots sampled each year, 6 were selected for use in the field study and represented relatively low and high levels of $C$. coccodes and V. dahliae. The incidence of infected seed tubers in seed lots planted in 2007 was 0 to 60 and 0 to $11 \%$ for $C$. coccodes and $V$. dahliae, respectively. The incidence of infected seed tubers was 9 to $80 \%$ for $C$. coccodes and 0 to $14 \%$ for $V$. dahliae for seed lots planted in 2008 (Table 1).

Field trials were carried out in 2007 and 2008 at the Washington State University (WSU) Experimental Station near Othello $\left(46^{\circ} 47^{\prime} 14.46^{\prime \prime} \mathrm{N}, 119^{\circ} 02^{\prime} 38.60^{\prime \prime} \mathrm{W}\right)$, and in commercial potato fields near Connell $\left(46^{\circ} 41^{\prime} 18.92^{\prime \prime} \mathrm{N}, 118^{\circ} 51^{\prime} 17.09^{\prime \prime} \mathrm{W}\right)$ in the Columbia Basin of Washington State. Different fields were used each year and the same seed lots were planted at the two locations. Trials at the WSU Experimental Station were carried out on a Shano silt loam in fields planted to potato on a 5-year rotation (potato every fifth year) for many decades. Trials carried out on this rotation will be referred to as 5-year potato rotation plots throughout this article. Trials carried out near Connell, WA were planted on a Chedahap fine sandy loam soil in 2007 and on Shano silt loam in 2008. The field near Connell used in 2007 had never been planted to potato, whereas the field used in 2008 had not been planted to potato for 30 years. The plots near Connell will be referred to as long potato rotation plots throughout the article. All fields were irrigated with overhead sprinkler irrigation systems.

The seed lots were planted at both locations on 3 May 2007 and 24 April 2008. Seed tubers that were not assayed from the selected six assayed seed lots were removed from $4^{\circ} \mathrm{C}$ storage and cut into 56- to 113-g (2- to 4-oz) seed pieces. Seed pieces were planted at a depth of $20 \mathrm{~cm}$ and spaced approximately $25 \mathrm{~cm}$ apart. Seed pieces from the six selected seed lots were planted in three-row plots with a length of $4.6 \mathrm{~m}$, and the distance between rows was $86 \mathrm{~cm}$. This provided a population of approximately 45,588 plants $\mathrm{ha}^{-1}$. The center row was used for yield evaluation and an adjacent row was used to assess the amount of plant colonization by $C$. coccodes and $V$. dahliae. All three rows were used to evaluate canopy necrosis. The seed lots were arranged in a randomized complete block design with four blocks. The insecticide thiamethoxam (Platinum, 8 $\mathrm{oz}$ acre $^{-1}$; Syngenta, Wilmington, DE) was applied in-furrow at planting at a rate of $140 \mathrm{~g}$ a.i. $\mathrm{ha}^{-1}$. Fungicides or seed treatments were not used at planting. Both fields were otherwise managed according to standard practices used in the Columbia Basin, except the irrigation system was inoperative for 10 days in the long potato rotation field during the last week of June and first week of July in 2007.

Black dot disease assessment. Internal colonization of aboveground stems by $C$. coccodes was assessed in three intact plants (subsamples) which were removed from each plot at 109 days after planting (DAP) in the 5-year potato rotation field and at 125 DAP in the long potato rotation field in 2007. Internal colonization of aboveground stems was assessed in both fields at 119 DAP in 2008. The sampled plants were dug and petioles removed using pruning shears. Plants were placed in coolers for transportation and stored overnight at $4^{\circ} \mathrm{C}$. The following day, plants were rinsed in

Table 1. Disease severity and yield characteristics of potato seed lots with and without Colletotrichum coccodes- and Verticillium dahliae-infected tubers planted in fields under 5-year and long potato rotations ${ }^{\mathrm{r}}$

\begin{tabular}{|c|c|c|c|c|c|c|c|c|c|c|c|c|c|c|c|c|c|c|c|}
\hline \multirow{2}{*}{\multicolumn{2}{|c|}{ Infected $(\%)^{\mathrm{s}}$}} & \multicolumn{6}{|c|}{ C. coccodes disease severity } & \multicolumn{8}{|c|}{ V. dahliae disease severity } & \multicolumn{4}{|c|}{ Yield } \\
\hline & & \multicolumn{2}{|c|}{ Stem $^{t}$} & \multicolumn{2}{|c|}{ Root disease $^{\mathrm{u}}$} & \multicolumn{2}{|c|}{$\begin{array}{c}\text { Infected } \\
\text { tubers }(\%)^{\mathbf{v}}\end{array}$} & \multicolumn{2}{|c|}{ Vascular $^{\mathrm{t}}$} & \multicolumn{2}{|c|}{ Necrosis $(\%)^{\mathrm{w}}$} & \multicolumn{2}{|c|}{$\begin{array}{l}\text { Infected } \\
\text { plants }^{w}\end{array}$} & \multicolumn{2}{|c|}{$\begin{array}{c}\text { Infected } \\
\text { tubers }(\%)^{\mathbf{v}}\end{array}$} & \multicolumn{2}{|c|}{$\begin{array}{c}\text { Number of } \\
\text { tubers }^{x}\end{array}$} & \multicolumn{2}{|c|}{ Ton ha ${ }^{-1 x}$} \\
\hline $\mathrm{CC}$ & VD & 5-year & Long & 5-year & Long & 5-year & Long & 5-year & Long & 5-year & Long & 5-year & Long & 5-year & Long & 5-year & Long & 5-year & Long \\
\hline \multicolumn{20}{|l|}{2007} \\
\hline 0 & 0 & $3.0 \mathrm{a}$ & 0.0 & 0.6 & 0.2 & 2.0 & 0.0 & 5.8 & 1.5 & 47 & 11 & $4.3 \mathrm{bc}$ & 3.3 & 23.5 & $14.0 \mathrm{a}$ & $175 \mathrm{abc}$ & $206 a b$ & $87.4 \mathrm{a}$ & $79.6 \mathrm{ab}$ \\
\hline 25 & 0 & $1.1 \mathrm{~b}$ & 0.0 & 0.4 & 0.0 & 1.8 & 0.0 & 6.0 & 1.5 & 45 & 10 & $4.0 \mathrm{bc}$ & 2.5 & 39.3 & $14.0 \mathrm{a}$ & $179 a b c$ & $205 \mathrm{ab}$ & $72.2 \mathrm{~b}$ & $85.0 \mathrm{a}$ \\
\hline 31 & 0 & $0.7 \mathrm{~b}$ & 0.0 & 0.3 & 0.3 & 3.5 & 0.0 & 6.0 & 2.3 & 48 & 11 & $3.8 \mathrm{c}$ & 1.8 & 23.3 & $7.0 \mathrm{ab}$ & $184 \mathrm{ab}$ & $166 \mathrm{~b}$ & $83.4 \mathrm{a}$ & $63.0 \mathrm{~b}$ \\
\hline 54 & 3 & $2.3 \mathrm{ab}$ & 0.0 & 0.5 & 0.1 & 1.8 & 1.8 & 6.0 & 2.3 & 45 & 15 & $4.5 \mathrm{abc}$ & 3.5 & 33.8 & $0.0 \mathrm{~b}$ & $193 \mathrm{a}$ & $194 \mathrm{ab}$ & $74.9 \mathrm{~b}$ & $78.2 \mathrm{ab}$ \\
\hline 57 & 3 & $0.5 \mathrm{~b}$ & 0.0 & 0.6 & 0.0 & 3.5 & 0.0 & 6.0 & 1.1 & 60 & 13 & $7.3 \mathrm{a}$ & 4.0 & 25.0 & $5.3 \mathrm{~b}$ & $158 \mathrm{c}$ & $190 \mathrm{ab}$ & $74.2 \mathrm{~b}$ & $76.2 \mathrm{ab}$ \\
\hline 60 & 11 & $0.8 \mathrm{~b}$ & 0.0 & 0.6 & 0.4 & 9.3 & 0.0 & 6.0 & 1.6 & 60 & 11 & $6.8 \mathrm{ab}$ & 3.3 & 21.5 & $9.3 \mathrm{ab}$ & $169 \mathrm{bc}$ & $221 \mathrm{a}$ & $78.7 \mathrm{ab}$ & $85.4 \mathrm{a}$ \\
\hline $\operatorname{LSD}^{\mathrm{y}}$ & $\ldots$ & $1.9^{\mathrm{z}}$ & NS & NS & NS & NS & NS & NS & NS & NS & NS & 2.8 & NS & NS & 9.3 & 22 & 52 & 11.5 & 17.2 \\
\hline \multicolumn{20}{|l|}{2008} \\
\hline 9 & 0 & $3.0 \mathrm{~b}$ & 0.6 & $0.7 \mathrm{~b}$ & $0.2 \mathrm{~b}$ & $32.3 \mathrm{ab}$ & 7.0 & 5.7 & 5.0 & $85 \mathrm{~b}$ & 10 & 8.0 & 0.0 & $34.3 \mathrm{ab}$ & $1.4 \mathrm{c}$ & $128 \mathrm{~b}$ & 145 & 61.4 & $86.3 \mathrm{~b}$ \\
\hline 11 & 0 & $4.4 \mathrm{a}$ & 0.1 & $0.8 \mathrm{ab}$ & $0.3 \mathrm{~b}$ & $17.8 \mathrm{~b}$ & 8.6 & 5.6 & 4.5 & $89 a b$ & 5 & 10.0 & 0.3 & $26.8 \mathrm{~b}$ & $10.5 \mathrm{a}$ & $128 \mathrm{~b}$ & 181 & 60.3 & $91.2 \mathrm{ab}$ \\
\hline 23 & 0 & $3.3 \mathrm{ab}$ & 0.0 & $1.0 \mathrm{ab}$ & $0.2 \mathrm{~b}$ & $18.7 \mathrm{~b}$ & 2.3 & 5.3 & 4.4 & $84 \mathrm{~b}$ & 6 & 10.0 & 0.0 & $48.3 \mathrm{a}$ & $0.0 \mathrm{c}$ & $125 \mathrm{~b}$ & 145 & 60.1 & $83.4 \mathrm{~b}$ \\
\hline 43 & 3 & $2.8 \mathrm{~b}$ & 0.0 & $1.1 \mathrm{ab}$ & $0.3 \mathrm{ab}$ & $21.3 \mathrm{ab}$ & 3.5 & 6.0 & 3.7 & $95 \mathrm{a}$ & 7 & 9.0 & 0.3 & $36.0 \mathrm{ab}$ & $9.3 \mathrm{ab}$ & $130 \mathrm{~b}$ & 147 & 67.7 & $83.4 \mathrm{~b}$ \\
\hline 57 & 11 & $2.4 \mathrm{~b}$ & 0.0 & $1.2 \mathrm{ab}$ & $0.5 \mathrm{ab}$ & $30.5 \mathrm{ab}$ & 5.3 & 6.0 & 4.2 & $91 \mathrm{ab}$ & 9 & 9.0 & 0.5 & $41.0 \mathrm{ab}$ & $3.5 \mathrm{bc}$ & $155 \mathrm{a}$ & 172 & 75.1 & $97.5 \mathrm{a}$ \\
\hline 80 & 14 & $3.3 \mathrm{ab}$ & 0.3 & $1.4 \mathrm{a}$ & $0.8 \mathrm{a}$ & $37.5 \mathrm{a}$ & 9.3 & 6.0 & 5.3 & $90 \mathrm{ab}$ & 9 & 8.0 & 0.5 & $28.5 \mathrm{~b}$ & $10.5 \mathrm{a}$ & $153 \mathrm{a}$ & 169 & 70.8 & $85.2 \mathrm{~b}$ \\
\hline $\operatorname{LSD}^{y}$ & $\ldots$ & 1.4 & NS & 0.6 & 0.4 & 18.6 & NS & NS & NS & 9 & NS & NS & NS & 15.2 & 6.3 & 17 & NS & NS & 10.7 \\
\hline
\end{tabular}

$\mathrm{r}$ Five-year rotation fields were planted to potato every 5 years while long rotation fields were not planted to potato in at least 30 years.

s Incidence of $C$. coccodes (CC) and $V$. dahliae (VD) in seed lots was determined by plating the stem ends from a subsample of 30 surface-sterilized tubers on NP-10 medium.

$\mathrm{t}$ Aboveground stem and vascular colonization severity values of 0 to 5 were based on the maximum height of vascular colonization above the soil line at 2 , 6 , and $12 \mathrm{~cm}$ using the following formula: $\left[\left(1 \times x_{2}\right)+\left(2 \times x_{6}\right)+\left(3 \times x_{12}\right)\right]$, where $x_{\mathrm{y}}=$ the binomial response at stem height $y$. Values for each cross-section were then totaled within each subsample and the mean value across subsamples was calculated for each plot.

u Root disease severity. Roots were evaluated for extent of $C$. coccodes colonization and received a score of 0 to 4 for the percent area of the roots that were covered with sclerotia using the following scale: no sclerotia $=0,1$ to $25 \%=1,26$ to $50 \%=2,51$ to $75 \%=3$, and 76 to $100 \%=4$.

${ }^{v}$ Percent infected progeny tubers. Incidence of $C$. coccodes and $V$. dahliae in progeny tubers was determined by plating the stem ends from a subsample of 14 surface-sterilized tubers on NP-10 medium.

${ }^{w}$ Mean crop canopy necrosis and the number of infected plants exhibiting $V$. dahliae microsclerotia on stems were visually assessed in each plot prior to vine-kill.

$x$ Yields were taken from the center row of each plot and tubers were mechanically weighed and counted, and total yields per hectare were calculated.

y Comparisons between treatment means were performed using Fisher's protected least significant difference (LSD) tests at $\alpha=0.05$, except where indicated. NS = not significant.

z Significant at $P=0.06$. 
tap water, surface disinfected in a $0.5 \% \mathrm{NaOCl}$ solution for $5 \mathrm{~min}$, and rinsed in distilled water. Cross-sections ( $5 \mathrm{~mm}$ in length) were removed at 2,6 , and $12 \mathrm{~cm}$ above the soil line and plated onto NP10 medium. Plates were incubated at $23^{\circ} \mathrm{C}$ for 14 days and evaluated for the presence of $C$. coccodes colonies. Positive identifications were verified microscopically or by subculturing onto potato dextrose agar when necessary. Internal colonization was recorded at each of the three heights as a binomial response, with $1=$ presence of $C$. coccodes and $0=$ absence of $C$. coccodes (28). Each stem was assigned a disease severity index (DSI) value of 0 to 5 which was based on maximum vascular colonization height above the soil line at 2,6, and $12 \mathrm{~cm}$ using the following formula: DSI $=$ $\left[\left(1 \times x_{2}\right)+\left(2 \times x_{6}\right)+\left(3 \times x_{12}\right)\right]$, where $x_{y}=$ the binomial response at stem height $y$. The values for each cross-section were then totaled within each subsample and the mean value across subsamples was calculated for each plot.

The same three plants (subsamples) used to assess aboveground stem colonization were also evaluated for root colonization by $C$. coccodes. Belowground stems and roots of the three plants were rinsed in tap water, surface disinfected in a $0.5 \% \mathrm{NaOCl}$ solution for $5 \mathrm{~min}$, rinsed in distilled water, air dried for about $1 \mathrm{~h}$, and then placed in a single polyethylene bag (20 by 10 by $45 \mathrm{~cm}$ ) with the aboveground stems extending from the top of the bag. A twist tie was placed around the bag and stems at the crown of the plant, and the whole unit was stored upright for 12 days. The bag was secured loosely around the three stems so that a pencil could be inserted into the neck, permitting air exchange and reducing bacterial decay. Roots were evaluated for extent of $C$. coccodes colonization by observing for sclerotia after 12 days in the modified moist chamber. Each root system received a score of 0 to 4 for the percent area of the roots that were covered with sclerotia using the following scale: no sclerotia $=0,1$ to $25 \%=1,26$ to $50 \%=2,51$ to $75 \%=3$, and 76 to $100 \%=4$.

Verticillium wilt disease assessment. Aboveground vascular colonization by $V$. dahliae was determined at 109 DAP in the 5year potato rotation field, 125 DAP in the long potato rotation field in 2007, and 119 DAP in both fields during 2008. Aboveground vascular colonization was assessed by plating stem sections onto NP-10 medium as described for $C$. coccodes. Total crop canopy necrosis and the number of infected plants exhibiting $V$. dahliae microsclerotia on stems were visually assessed in each plot prior to vine-kill at 119 DAP in the 5-year potato rotation field in 2007 and at 137 DAP in both fields in 2008. Crop canopy necrosis and the number of Verticillium spp.-infected plants were assessed in the long potato rotation field in 2007 at 125 and 130 DAP, respectively.

Yield assessment and progeny tuber assays. Plots were dug at 125 DAP in the 5-year potato rotation field and at 131 DAP in the long potato rotation field in 2007. Both the 5-year and long potato rotation fields were dug at 146 DAP in 2008. Yields were taken from the center row of each plot and tubers were mechanically weighed and counted, and total yields per hectare were calculated. Progeny tubers were assessed for internal infection by $C$. coccodes and $V$. dahliae as described above using 14 tubers randomly selected from each plot.

Data analysis. Analysis of variance was conducted using PROC GLM in SAS (version 9.1; SAS Institute, Cary, NC) to test for significant differences in disease severity and yield among seed lots. Comparisons between treatment means were performed using Fisher's protected least significant difference tests. Relationships between the incidences of seed tubers infected with each pathogen within seed lots and disease severity variables that were determined in the field were examined using regression analysis with PROC REG in SAS. Vascular colonization severity indices of both pathogens, severity of black dot on roots, the total number of Verticillium spp.-infected plants, overall crop canopy necrosis, and incidence of infected progeny tubers infected were treated as dependent variables and were regressed against the incidence of seed infected with each pathogen within seed lots. Regression analysis was also performed using progeny tuber quantity and yield as dependent variables. The percentage of infected seed per lot planted in the 2007 potato rotation field was transformed $(\log +1)$ to satisfy assumptions of normality. Multiple regression analysis was performed to test for significant linear relationships using the incidences of both pathogens in seed lots on disease severity and yield. All inferences were carried out at a 5\% significance level.

\section{Results}

Severity of internal colonization by $C$. coccodes in aboveground stems differed significantly among seed lots in the 5-year potato fields in $2007(P=0.06)$ and $2008(P=0.05)$ but was not $(P>$ $0.05)$ related to the incidence of $C$. coccodes in seed lots (Table 1 ). Colonization in stems did not differ among seed lots in the long rotation potato fields. In 2007, severity of black dot on roots did not differ among seed lots or show a relationship with seed lot incidence. Severity of black dot on roots differed significantly among seed lots (Table 1), and severity on roots increased as incidence in seed lots increased in the 5-year potato rotation field $\left(R^{2}=0.94 ; P<0.001\right)$ and long potato rotation field $\left(R^{2}=0.89 ; P=0.01\right)$ in 2008 (Fig. 1). Incidence of seed lot infection by $C$. coccodes was not significantly related to the incidence of progeny tuber infection $(P>0.05)$, except in the 5-year potato rotation field in 2008.

With $V$. dahliae, no differences were evident among seed lots in aboveground vascular colonization (Table 1). Crop canopy necrosis due to Verticillium wilt significantly differed among seed lots only in the 5-year potato rotation field in 2008 (Table 1). The number of infected plants with stems colonized by $V$. dahliae microsclerotia at vine-kill only differed significantly among seed lots in the 5-year potato rotation field in 2007 (Table 1). The number of infected plants exhibiting microsclerotia on stems increased as incidence of seed lot infection increased in the 5-year potato rotation field in
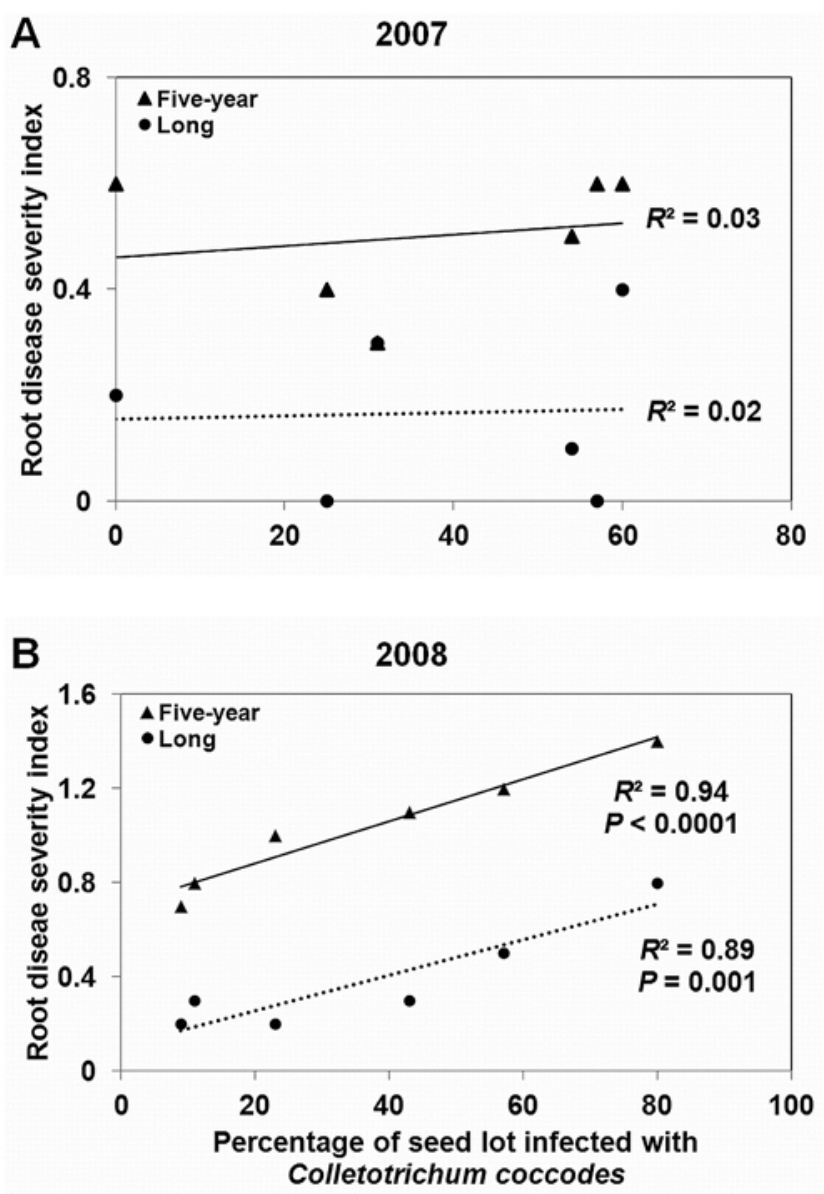

Fig. 1. Regression analysis of potato seed lots with varying amounts of Colletotrichum coccodes infection and disease severity of roots at harvest in $\mathbf{A}$, 2007 and B, 2008. Seed tubers were planted in fields under 5-year potato rotations (solid line) and in long-rotation fields which had not grown potato in 30 years (dotted line). Only significant $(\alpha=0.05) P$ values are shown. 
$2007\left(R^{2}=0.65 ; P=0.05\right)$ and in the long potato rotation field in $2008\left(R^{2}=0.80 ; P=0.02\right)$ but not in the long potato rotation field in 2007 or the 5-year potato rotation field in 2008 (Fig. 2). The incidence of $V$. dahliae infection in progeny tubers differed significantly among seed lots in the 5-year potato rotation field in 2008 and both years in the long potato rotation fields (Table 1). All seed lots ranked worse for all disease variables in 5-year potato rotation fields when compared with long potato rotation fields.

Yield differed significantly among seed lots in both the 5-year and long potato rotation fields in 2007 and in the long potato rotation field in 2008 (Table 1). The number of harvested progeny tubers also differed significantly among seed lots in three of four fields (Table 1). Yield and number of progeny tubers each increased as incidence of black dot infection in seed tubers increased in the 5-year potato rotation field in $2008\left(R^{2}=0.74 ; P=0.03\right)$ but relationships were not found in $2007(P>0.10)$. Yield was not significantly related to incidence of infection of $V$. dahliae in seed tubers. Nevertheless, decreased progeny tuber quantity was related to increased $V$. dahliae infection in seed lots in the long potato rotation field in $2008\left(R^{2}=0.80 ; P=0.02\right)$. Multiple regression models, using the incidences of both pathogens in seed lots as independent variables, were not significantly related to yield or the number of progeny tubers in either year $(P>0.05)$.

\section{Discussion}

In general, black dot disease symptoms and yield reductions were not related to levels of the pathogen in seed lots. Relation-
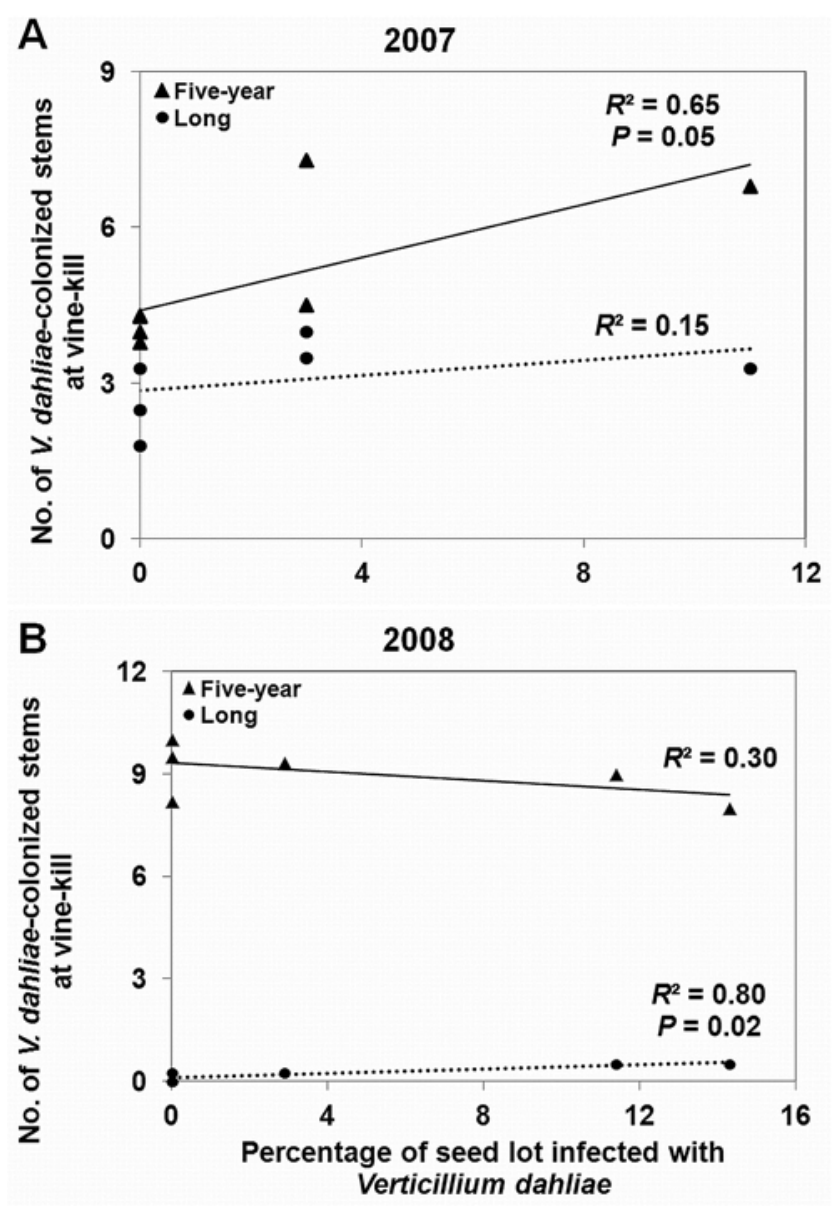

Fig. 2. Regression analysis of potato seed lots with varying amounts of Verticillium dahliae infection and the number of $V$. dahliae-colonized potato stems at vine-kill in A, 2007 and B, 2008. Seed tubers were planted in fields under 5-year potato rotations (solid line) and in long-rotation fields which had not grown potato in 30 years (dotted line). The percentage of infected seed per lot planted in the 20075 year potato rotation field was transformed $(\log +1)$ to satisfy assumptions of normality for analysis and back-transformed for presentation. Only significant $(\alpha=$ $0.05) P$ values are shown. ships between the incidence of seed lot infection by $C$. coccodes and black dot severity or yield were not consistent over all four fields and did not adequately explain the differences in black dot symptoms observed among the seed lots. The incidence of seed lot infection by $C$. coccodes was related to yield in the 5-year potato rotation field in 2008 but the relationship was positive, with higher yields resulting from seed lots more heavily infected with black dot. A significant and positive relationship between the incidence of $C$. coccodes in seed lots and number of $C$. coccodes-infected progeny tubers was observed in the same field, and the greater yields may have been a product of the increased tuber set. Yield reductions due to $C$. coccodes have been demonstrated in previous studies; however, these were the result of foliar inoculation using airborne inoculum or inoculation of belowground plant parts with soilborne inoculum rather than tuberborne inoculum $(17,24,40)$. Data from this study indicate that tuberborne inoculum of $C$. coccodes and, specifically, internal infection of seed tubers does not play a major and consistent role in promoting black dot disease symptoms in the field or in reducing plant yields. This is in agreement with previous research, wherein tubers with external infection or artificially inoculated tubers were used $(1,26,30,32)$.

Infected seed tubers likely played a major role in promoting colonization of roots and increased progeny tuber infection by $C$. coccodes in the long potato rotation field in 2008 . In previous studies, tuberborne inoculum of $C$. coccodes was demonstrated to contribute to progeny tuber infection and the pathogen had been shown to spread from infected seed along roots and stolons at a rate of 1 $\mathrm{mm} /$ day $(1,15,32)$. Mean root disease severity values in the 2008 long potato rotation field were 0.2 to 0.8 , which is equivalent to 1 to $25 \%$ of total root colonization by the pathogen according to the disease severity index used in this study. Root disease severity values approaching a value of 1 may be relevant in the field, because this indicates that nearly $25 \%$ of the root system is colonized by $C$. coccodes. Increased root colonization by $C$. coccodes may contribute to root rot, plant stress, reduced yields, and increased levels of soilborne inoculum. Aboveground stem colonization by C. coccodes was also observed in some plots in the long potato rotation field in 2008, which may have resulted from internal infection of seed tubers or airborne inoculum in the field. The use of Russet Burbank, a long-season variety, may have contributed to increased progeny tuber infection and aboveground stem colonization in the long potato rotation field (1).

Incidence of internal infection by $V$. dahliae in seed lots was also not related to canopy necrosis or infection of progeny tubers, nor was it related to differences in yield. The incidence of $V$. dahliaeinfected tubers in seed lots was associated with the severity of aboveground vascular colonization in two of four fields and a greater number of Verticillium spp.-infected plants in one field. However, all seed lots exhibited greater aboveground vascular colonization, more severe canopy necrosis, and higher incidences of Verticillium spp.-infected plants and progeny tubers when planted in 5-year potato rotation fields compared with long potato rotation fields in both years. This is consistent with previous studies on other cultivars, which concluded that vascular infection of seed tubers was not as important as soilborne inoculum in the development Verticillium wilt $(11,13,34,38)$. Seed lots with higher incidence of $V$. dahliae infection produced fewer progeny tubers in one of four fields but relationships were not found between seed lot infection and yield. Prior studies have reported variable effects of Verticillium wilt on yield and can be affected by fertility, irrigation, and environmental conditions $(25,31,35)$.

Although a lack of repetition prohibited formal statistical comparisons between the 5-year and long potato rotation fields, differences in disease severity were evident and expected. C. coccodes was detected in aboveground stems collected from all treatments in the 5-year potato rotation fields but not from aboveground stems in the long potato rotation field in 2007, and black dot symptoms were generally less severe in long potato rotation fields. Five-year potato rotation fields had more $V$. dahliae-infected plants at vinekill, increased severity of vascular colonization in aboveground 
stems, and a greater incidence of $V$. dahliae infection in progeny tubers than long potato rotation fields. Canopy necrosis was greater in the two 5-year potato rotation fields compared with two long potato rotation fields. In addition, all but two of the seed lots planted in long potato rotation fields had higher yields compared with the same seed lot planted in 5-year potato rotation fields during the same year.

Nearly parallel linear relationships were observed between the two field types for levels of infected tubers and both $C$. coccodes root disease severity and $V$. dahliae colonization of stems at vinekill. The lower y-intercept values in the long potato rotation fields in both years indicated that a major difference between the two fields was likely the amount of primary inoculum in the field. Although inoculum levels in the fields were not quantified, the amount of soilborne inoculum required to cause black dot and Verticillium wilt in potato can be relatively low, from as few as 6 sclerotia $\mathrm{cm}^{-3}$ of soil for C. coccodes (26) and between 5 and 30

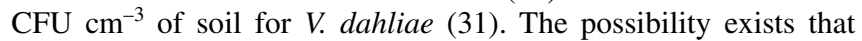
inoculum residing in soil eclipsed any minor effects of vascular infection of seed tubers, especially in the 5-year potato rotation fields. Additionally, the incidence of $V$. dahliae infection within certified seed lots is generally less than $5 \%(29,39)$ and the pathogen may not be present in numbers to significantly contribute to disease in the field.

The results obtained from this study suggest that the incidence of internal infection by $C$. coccodes or $V$. dahliae in certified seed lots is not related to black dot or Verticillium wilt severity or reduced yield and is not a reliable predictor of final disease. Although infected seed tubers are not as important as soilborne inoculum in the development of current-season symptoms, they may contribute to the dissemination and establishment of $C$. coccodes and $V$. dahliae in potato production areas or fields which have been subjected to fumigation or other management practices. In this study, seed lots grown in fields under 5-year potato rotations generally had higher disease severity and lower yields than seed lots grown in long potato rotation fields. The reasons for yield differences among seed lots within a field are not known but it was observed that one seed lot produced the highest yield and another seed lot produced the lowest yield in both fields planted in 2008 . Possible reasons for yield differences among seed lots include slight genetic differences among clones, the geographic origin or physiological age of the seed lot, or a combination of factors $(22,23)$. The differences in yield among the seed lots emphasize the importance of seed lot selection and the recommended guidelines and best practices for potato seed lot selection $(4,12,36)$, which should be considered when choosing and handling seed tubers for production. Considering the role of seed tuber infection in the development of black dot and Verticillium wilt in Russet Burbank potato, other factors such as physiological age, disease resistance, and freedom from other, more important tuberborne pathogens should be of more concern unless the field has not previously been planted to potato.

\section{Acknowledgments}

We thank L. Porter and N. Nitzan for critical reviews of the manuscript and the Washington State Potato Commission for financial support.

\section{Literature Cited}

1. Andrivon, D., Lucas, J. M., Guerin, C., and Jouan, B. 1998. Colonization of roots, stolons, tubers, and stems of various potato (Solanum tuberosum) cultivars by the black-dot fungus Colletotrichum coccodes. Plant Pathol. 47:440-445.

2. Barkdoll, A. W., and Davis, J. R. 1992. Distribution of Colletotrichum coccodes in Idaho and variation in pathogenicity on potato. Plant Dis. 76:131135 .

3. Bender, J. M., Stevenson, W. R., Keeler, R. R., and Huber, D. M. 1976. Characterization of three species of the genus Colletotrichum with aminopeptidase profiles (Colletotrichum coccodes, Colletotrichum graminicola and Colletotrichum gloeosporioides). Proc. Indiana Acad. Sci. 85:318323

4. Bohl, W. H., Olsen, N., Love, S. L., and Nolte, P. 2003. Seed and planting management. Pages 91-113 in: Potato Production Systems. J. C. Stark and S. L. Love, eds. University of Idaho Agricultural Communications, Moscow.
5. Butterfield, E. J., and Devay, J. E. 1977. Reassessment of soil assays for Verticillium dahliae. Phytopathology 67:1073-1078.

6. Cappaert, M. R., Powelson, M. L., Christensen, N. W., and Crowe, F. J. 1992. Influence of irrigation on severity of potato early dying and tuber yield. Phytopathology 82:1448-1453.

7. Dashwood, E. P., Fox, R. A., and Perry, D. A. 1992. Effect of inoculum source on root and tuber infection by potato blemish disease fungi. Plant Pathol. 41:215-223.

8. Denner, F. D. N., Millard, C. P., and Wehner, F. C. 1998. The effect of seedand soilborne inoculum of Colletotrichum coccodes on the incidence of black dot on potatoes. Potato Res. 41:51-56.

9. Dickson, B. T. 1926. The "black dot" disease of potato. Phytopathology 16:23-40.

10. Domsch, K. H., Gams, W., and Anderson, T.-H. 1980. Compendium of Soil Fungi. Academic Press, New York.

11. Dung, J. K. S., and Johnson, D. A. 2012. Roles of infected seed tubers and soilborne inoculum on Verticillium wilt of 'Russet Burbank' potato. Plant Dis. 96:379-383.

12. Fennell, J., and de Jong, R. 1996. Effect of seed production location on the performance of Russet Burbank clones in southern Australia. Am. J. Potato Res. 73:569-575.

13. Hoyman, W. G. 1974. Consequence of planting Norgold Russet seed infected with Verticillium albo-atrum. Am. Potato J. 51:22-25.

14. Hunger, R. M., and McIntyre, G. A. 1979. Occurrence, development, and losses associated with silver scurf and black dot on Colorado potatoes. Am Potato J. 56:289-306.

15. Ingram, J., and Johnson, D. 2010. Colonization of potato roots and stolons by Colletotrichum coccodes from tuberborne inoculum. Am. J. Potato Res 87:382-389.

16. Isaac, I. 1967. Speciation in Verticillium. Annu. Rev. Phytopathol. 5:201222.

17. Johnson, D. A. 1994. Effect of foliar infection caused by Colletotrichum coccodes on yield of Russet Burbank potato. Plant Dis. 78:1075-1078.

18. Johnson, D. A., and Dung, J. K. S. 2010. Verticillium wilt of potato-the pathogen, disease and management. Can. J. Plant Pathol. 32:58-67.

19. Johnson, D. A., Rowe, R. C., and Cummings, T. F. 1997. Incidence of Colletotrichum coccodes in certified potato seed tubers planted in Washington State. Plant Dis. 81:1199-1202.

20. Johnson, K. B., Radcliffe, E. B., and Teng, P. S. 1986. Effects of interacting populations of Alternaria solani, Verticillium dahliae, and the potato leafhopper (Empoasca fabae) on potato yield. Phytopathology 76:1046-1052.

21. Komm, D. A., and Stevenson, W. R. 1978. Tuber-borne infection of Solanum tuberosum 'Superior' by Colletotrichum coccodes. Plant Dis. Rep. 62:682-687

22. Love, S., Thompson, A., Baker, T., and Corsini, D. 1992. Comparison of Russet Burbank clones from various geographical regions of the United States and Canada. Am. J. Potato Res. 69:299-307.

23. Miller, J., Smallwood, D., Miller, J., and Fernandez, G. 1995. Norgold Russet and Norgold Russet strain M-additional evidence for genetic dissimilarity. Am. J. Potato Res. 72:273-286.

24. Mohan, S. K., Davis, J. R., Sorensen, L. H., and Schneider, A. T. 1992. Infection of aerial parts of potato plants by Colletotrichum coccodes and its effects on premature vine death and yield. Am. Potato J. 69:547-559.

25. Nachmias, A., and Krikun, J. 1984. Transmission of Verticillium dahliae in potato tubers. Phytopathology 74:535-537.

26. Nitzan, N., Cummings, T. F., and Johnson, D. A. 2008. Disease potential of soil- and tuberborne inocula of Colletotrichum coccodes and black dot severity on potato. Plant Dis. 92:1497-1502.

27. Nitzan, N., Evans, M., and Johnson, D. A. 2006. Colonization of potato plants after aerial infection by Colletotrichum coccodes, causal agent of potato black dot. Plant Dis. 90:999-1003.

28. Nitzan, N., Evans, M. A., Cummings, T. F., Johnson, D. A., Batchelor, D. L., Olsen, C., Haynes, K. G., and Brown, C. R. 2009. Field resistance to potato stem colonization by the black dot pathogen Colletotrichum coccodes. Plant Dis. 93:1116-1122.

29. Omer, M. A., Johnson, D. A., and Rowe, R. C. 2000. Recovery of Verticillium dahliae from North American certified seed potatoes and characterization of strains by vegetative compatibility and aggressiveness. Am. J. Potato Res. 77:325-331

30. Pasche, J. S., Taylor, R. J., and Gudmestad, N. C. 2010. Colonization of potato by Colletotrichum coccodes: effect of soil infestation and seed tuber and foliar inoculation. Plant Dis. 94:905-914

31. Powelson, M. L., and Rowe, R. C. 1993. Biology and management of early dying of potatoes. Annu. Rev. Phytopathol. 31:111-126.

32. Read, P. J., and Hide, G. A. 1988. Effects of inoculum source and irrigation on black dot disease of potatoes (Colletotrichum coccodes (Wallr.) Hughes) and its development during storage. Potato Res. 31:493-500.

33. Read, P. J., and Hide, G. A. 1995. Development of black dot disease (Colletotrichum coccodes (Wallr.) Hughes) and its effects on the growth and yield of potato plants. Ann. Appl. Biol. 127:57-72

34. Robinson, D. B., and Ayers, G. W. 1961. Verticillium wilt of potato in relation to vascular infection of the tuber. Can. J. Plant Sci. 41:703-708.

35. Rowe, R. C., Riedel, R. M., and Martin, M. J. 1985. Synergistic interactions between Verticillium dahliae and Pratylenchus penetrans in potato early dy- 
ing disease. Phytopathology 75:412-418.

36. Secor, G. A., and Johnson, S. B. 2008. Seed tuber health before and during planting. Pages 43-53 in: Potato Health Management. D. A. Johnson, ed. American Phytopathological Society, St. Paul, MN.

37. Stevenson, W. R., Loria, R., Franc, G. D., and Weingartner, D. P., eds. 2001. Compendium of Potato Diseases, 2nd ed. American Phytopathological Society, St. Paul, MN.

38. Thanassoulopoulos, C. C., and Hooker, W. J. 1968. Factors influencing infection of field grown potato by Verticillium albo-atrum. Am. Potato J. 45:203-216.

39. Tsror (Lahkim), L., Aharon, M., and Erlich, O. 1999. Survey of bacterial and fungal seedborne diseases in imported and domestic potato seed tubers. Phytoparasitica 27:215-226.

40. Tsror (Lahkim), L., Erlich, O., and Hazanovsky, M. 1999. Effect of Colletotrichum coccodes on potato yield, tuber quality, and stem colonization during spring and autumn. Plant Dis. 83:561-565. 